\title{
The Relationship between Direct Language Learning Strategies and English Learning Proficiency at Senior High School Students
}

\author{
Rizal Arisman ${ }^{1}$ \\ ${ }^{1}$ Universitas Dayanu Ikhsanuddin \\ email: rizalarisman@unidayan.ac.id
}

\begin{abstract}
Learning strategies are applied by students to improve their studies. Suitable language learning strategies result in proficiency which is improved and greater self-confidence. Most researches observe the language learning strategies without dividing which affect more between direct and indirect strategy toward learning proficiency. Therefore, this research was conducted to find out whether the direct language learning strategies had a positive relationship and significant effect toward English learning proficiency on senior high school students. An ex-post-facto method with a correlational design was applied in this research. The population was 410 students at the eleventh grade of SMA Negeri 1 Baubau and selected 75 students as the sample using a simple random sampling technique. The instruments used were the SILL (Strategy Inventory for Language Learning) and the English proficiency test. The results of descriptive statistics indicate the compensation strategies were the most dominant learning strategy used by the eleventh-grade students with the mean score was 2.66. From the result of hypothesis testing, it was obtained the positive relationships and significant effect of those three kinds of strategies toward English proficiency on the eleventh-grade students. Besides, the memory strategies have the highest correction with the score of correlation is 0.756 .
\end{abstract}

Keywords: Language learning strategies, English proficiency

\begin{abstract}
Abstrak
Strategi belajar adalah Langkah yang diambil oleh siswa untuk meningkatkan pembelajarannya. Strategi belajar yang cocok menghasilkan peningkatan kemampuan dan kepercayaan diri yang lebih tinggi. Kebanyakan penelitian mengamati strategi pembelajaran bahasa tanpa membagi mana yang lebih memiliki dampak antara strategi langsung dan tidak langsung terhadap kemampuan belajar. Oleh karena itu, penelitian ini dilaksanakan untuk mengetahui apakah strategi belajar bahasa langsung memiliki hubungan yang positif dan dampak yang signifikan terhadap kemampuan belajar bahasa Inggris siswa kelas sebelas. Metode eks-post fakto dengan desain korelasi diterapkan dalam penelitian ini. Populasi sebanyak 410 siswa kelas sebelas SMA Negeri 1 Baubau dan dipilih 75 siswa sebagai sampel penelitian menggunakan teknik sampel acak sederhana. Instrumen-instrumen yang digunakan adalah SILL (Strategy Inventory for Language Learning/Daftar Strategi Pembelajaran Bahasa) dan tes kemampuan bahasa Inggris. Hasil statistik deskrpitif menunjukkan strategi kompensasi adalah strategi pembelajaran yang paling dominan
\end{abstract}


digunakan oleh siswa kelas sebelas dengan nilai rerata sebesar 2,66. Dari hasil uji hipotesis, diperoleh hubungan yang positif dan dampak yang signifikan dari ketiga strategi tersebut terhadap siswa kelas sebelas. Selain itu, strategi memori memiliki hubungan yang paling tinggi dengan nilai hubungan sebesar 0.756 .

\section{Kata Kunci: Strategi pembelajaran Bahasa, kemampuan bahasa Inggris}

\section{INTRODUCTION}

Learning has an essential role in development, habit, attitude, belief, objective, personality, and even a human's perception. According to Whittaker in Darsono (2000), the definition of learning is as the procedures by which behavior originates or is altered through training or experience. Winkel in Darsono (2000) states that learning is a mental/psychics activity in interacting actively with the environment, which produces a change in knowledge, understanding, skill, and attitude. Learning is a set of mental activities to obtain a change of behavior as the result of individual experience in interacting with the environment related to cognitive, affective, and psychomotor (Djamarah, 2002). Furthermore, Slameto (2010) formulates the definition of learning, which is a process of effort done by an individual to gain a change of new behavior totally as a result of the individual experience itself in interacting with the environment.

The learning activity cannot be separated from education. Education is official and informal Procedures of learning applied to create an individual's knowledge, skills and approaches, understanding in a certain Field or domain and teaching (Richards \& Schmidt, 2010). The Indonesian government defines education in the law of the Republic of Indonesia number 20 the year 2003 section 1 subsection 1 that education is a deliberate and organized effort to actualize the learning environment and learning cycle to effectively improve the learners ' ability to have the religious spiritual power, selfawareness, temperament, intellect, noble morals and skills they, the people, the nation and the country needed. It can be said that to improve the students' potential must be done through the learning process.

In the school curriculum, the students just learn English two days a week. In each day, the time provided in the classroom is just ninety minutes. Therefore, they just have three hours to learn English in the classroom. The limited time the students have in school makes them be able to maximize their effort in learning outside the classroom or the school. Joining an English course or study club for instance. Students in higher education, in particular, have much more experience of English language learning and using various types of learning strategies which they consider either useful or not useful resources for their learning achievement. It is supported by (Cohen \& Macaro, 2007) who highlight that strategies are consciously selected; learners decide when to use strategies based on their belief that the strategies will be useful for a particular task and learning achievement. In turn, they may keep on using those learning strategies in the process of language learning (Suwanarak, 2019). A good learner was found to apply strategy within proactive and creative efforts in improving their learning (Dörnyei \& Ryan, 2015).

By considering how influential the role of learning strategies on students' learning achievement, the students must recognize what kind of learning strategies they employ to make their studying better. 
Proper language learning strategies lead to greater self-confidence and improved proficiency (Oxford, 1990). Language learning strategies implemented and applied by the teacher for students can give an impact on the effectiveness of teaching and learning a language in class and obtain learners' success in English skill (Yustitiasari, 2020). Additionally, the selection of appropriate strategies will produce a collection of learning strategies that is a set of strategies that individual learners have and develop to support their learning achievement through experience and time (Wong \& Nunan, 2011).

In an English subject classroom, Language Learning Strategies (LLSs) are important for two motives. To begin with, assessing the LLSs made use of by EFL students can, studying procedures that elucidated plan approaches demand. LLSs could be educated to assist them to reach better learning results (Chamot, 2005). Furthermore, particular strategies are useful to observe to aid students in developing their skill in language, which affect their success in learning achievement (Arif, 2020).

There are two kind of strategies in language learning, those are direct strategies and indirect strategies (Oxford, 1990). Direct strategies are strategies used by the students which directly take part in the target language, while indirect strategies are strategies used to support the study without directly take part to the target language. Since the learning in school is running directly with learning face to face between teacher and students, therefore the researcher assumed that direct learning strategies are worthy to observe related to the direct learning model. A research conducted by Naeimi and Foo (2015) by applying direct and indirect strategies in teaching vocabulary, the result revealed that the direct strategies were better than the indirect strategies to improve the vocabulary acquisition of Iranian learners.

Thus, this research is conducted to find out the effect of direct language learning strategies on English learning proficiency in a senior high school in Baubau, Southeast Sulawesi. It was done be because the students did not understand the importance of LLSs on their learning proficiency. Besides, it can be a source of students to know what kind of learning strategies and what dominant strategies they employ in learning English.

\section{Language Learning Strategies}

Many experts have explained the nature of the strategies of learning. A learning approach would be really a succession of processes for attaining studying (Schmeck, 1988). They are also a particular thoughts or behaviors that people utilize to aid them understand, learn, or even maintain information that is new (O'Malley \& Chamot, 1990). Using correct learning strategies can assist students to achieve better learning achievement. A learning strategy can help a student in a context achieve learning goals that the student deems essential (Chamot, 2005). From those definitions, it can be summarized that the strategies of learning take part regardless of circumstance and content (Lessard-Clouston, 1997).

The research found that language learning strategies had effect on students' proficiency of language. A research conducted by Oflaz (2019) to investigate the relation between anxiety, shyness, language learning strategies, speaking scores, and academic achievement of foreign language on university preparatory students learning German. The result revealed that there was a significant positive relation between language learning 
strategies preferred by the students and academic achievement. Shyr et al. (2017) investigate the relationships between LLSs and achievement goal orientations (AGOs) in Taiwanese Engineering students taking an EFL (English as a Foreign Language) class. The significant correlation was identified between language learning strategies and achievement goal orientations. LLSs are also correlated to learning motivation, as research was conducted to investigate it and it was found that there was a significant relationship of strategies in language learning toward motivation in learning English (Barruansyah, 2018). Besides, high achiever mostly employed compensation, cognitive, and affective strategies (Taheri et al., 2020). More specific, Saricoban and Saricaoglu (2008) found the significant relationship compensation strategies and academic success of students

Oxford (1990) divides the LLS into two types, those are direct strategies and indirect strategies. Direct strategies are the language learning strategies that directly take part to the target language, while indirect strategies are the language learning strategies that support and manage language learning without (in many instances) directly take part to the target language. More specifically, she classifies the direct strategies into three groups, those are memory strategies, cognitive strategies, and compensation strategies.

Metacognitive, cognitive, and socioaffective strategies are other versions of learning strategies explained by another expert. Metacognitive, that is a word used in information processing theory to signify that an "executive" role, plans that demand preparation for learning, considering the learning process as it is happening, observation of the production or understanding, and evaluating learning later having an activity done (Purpura, 1997). Cognitive strategies demand direct manipulation of this educational material itself and tend to be restricted by specific learning activities. Socio-affective strategies must perform with interacting and action with other people (Brown, 2007). From those definitions, it can be summarized that the metacognitive strategies play more important roles to students than other strategies in the learning process, in which the cognitive strategies in restricted to the learning task and socioaffective strategies relate to students' social interaction.

Those taxonomies of language learning strategies indicate the seriousness of scholars to look at the value of strategies in language learning. Those taxonomies have precisely exactly the exact purposes. They demand to aid college students to be successful in mastering terminology. Kinds of those taxonomies intention to make easiness to see students from any prospective aspects of learning and teaching Including the appropriateness involving materials and learners, learners and instruction strategies, and learners and educators (Mattarima \& Hamdam, 2011).

\section{Proficiency}

The word of proficiency comes from proficient which means able to do something well because of training and practice (Hornby, 2010). Related to the proficiency tests, proficiency means having sufficient command of the language for a specific purpose. Proficiency in learning language could be defined as the degree of ability with which a person can work with vocabulary, such as someone can read, write, converse, or understand language. For more information on learners' proficiency, lecturers can apply proficiency test. 
Tests of proficiency are intended to assess an individual's skills in a language regardless of any training they may joined in that language (Hughes, 2003). The objective of a proficiency test does not refer to the objective of the language course in which someone who takes the test has joined before. A proficiency test can be done for a variety of purposes. The main purpose of the proficiency test is to make decisions about individual students. It means that in designing and implementing a writing proficiency assessment, it is critical to keep in mind that the primary function is to evaluate students as writers or their writing abilities (O’Neil et al., 2009).

\section{METHOD}

\section{Respondent}

This research used a qualitative approach with an ex-post-facto method of correlational design. Ex-post facto is a research design in which the researchers have no control over the selection and manipulation of the independent variable and examines the data retrospectively to establish possible causes, relationships or associations, and their meanings (Tavakoli, 2012). In this research, the researcher was interested to find out the level of relationship between two variables, those are three dependent variables: memory, cognitive, and compensation strategies, and an independent variable, which was English proficiency. This research involved 410 eleventh grade students of SMA Negeri 1 Baubau as the population. The sample was selected using a simple random sampling technique. It was the process of choosing a sample in a certain technique in which all students have the same chance to be the research's sample (Mills \& Gay, 2016). There were 75 students used as sample in this research.

\section{Instruments}

Two instruments used to collect the research data. The first instrument was a questionnaire of SILL (Strategy Inventory of Language Learning) developed by Oxford to collect the data of English learning strategies used by the students. The SILL included six categories of language learning strategies with 50 items divided into direct strategies (item 1-29) and indirect strategies (item 30-50). Since this research limited to the direct strategies, the categories used were just memory strategies, cognitive strategies, and compensation strategies which consisted of 29 items. The questionnaire had five options of Likert scale for students to choose based on what they perform in English class. The second instrument was a test. There were 20 items of multiple choice with four optional answers. The students were asked to do the test in 90 minutes. The test result provided the data of the students' English proficiency.

\section{Data Analysis}

After the data were collected, they were analyzed through Statistical Product and Service Solutions (SPPS) program version 21.0. The types applied were descriptive statistics, requirement testing, and inferential statistics. The descriptive statistics in this research was applied the mean score of each variables. Besides that, the descriptive statistics was also used to display the minimum and maximum score. Furthermore, the requirement analysis was applied after the general tendency data and the spread of scores have been obtained (Creswell, 2012).

The scores obtained from the questionnaire were then consulted to the scoring range to know the level of each category of students' strategies in learning English subject. It was divided into three 
parts: low, medium, and high strategy use (Ang et al., 2017) as presented in the following table:

Table 1: Scoring range and level of language learning strategy use.

\begin{tabular}{|c|c|}
\hline Level & Range \\
\hline High strategy use & $3.5-5.0$ \\
\hline Medium strategy use & $2.5-3.4$ \\
\hline Low strategy use & $1.0-2.4$ \\
\hline
\end{tabular}

For the descriptive statistics of the English proficiency test, since the test used was a multiple-choice test, then the score of each item was 1 for the correct answer and 0 for the incorrect answer. The raw scores were then converted into the 100-scale score using the following formula (Susetyo, 2015):

Score $=$ raw score $\times 100$

Ideal maximum score

After calculating the final score, it was consulted to the following table to know the level of students' English proficiency:

Table 2: Scoring range and category of students' English proficiency.

\begin{tabular}{|c|c|c|}
\hline No. & Level & Range \\
\hline 1. & Very good & $86-100$ \\
\hline 2. & Good & $71-85$ \\
\hline 3. & Moderate & $56-70$ \\
\hline 4. & Poor & $\leq 55$ \\
\hline
\end{tabular}

The next analysis was a requirement test. It covered the normality and the linearity test. Those tests were used to determine the data both were normally distributed and had a linear correlation and the inferential statistics was analyzed using parametric or nonparametric statistics. The parametric statistics was used when the data were not only normally distributed, but also the data variance was linear. If one of the requirements was not fulfilled, then the nonparametric statistics was carried on. The inferential statistics was done to test the hypothesis. To accept or reject the hypothesis, a Correlation Product Moment test was applied. The hypotheses in this research are formulated as follows:

a. There are a positive relationship and a significant effect between memory strategies on students' English proficiency.

b. There are a positive relationship and a significant effect between cognitive strategies and students' English proficiency.

c. There are a positive relationship and a significant effect between compensation strategies and students' English proficiency.

\section{FINDING AND DISCUSSION}

\section{Description of Learning Strategies and English Proficiency}

Since this research used SILL, the direct strategies had 30 items out of 50 items. The items left were the indirect strategies inventory. In the direct strategy inventory, the memory strategies took 9 items, the cognitive strategies took 14 items, and the compensation strategies took 6 items. While the English proficiency test had 20 items of multiple-choice. The results of the questionnaire and test were displayed in the following table:

Table 3: Mean score and category of memory strategies and English proficiency.

\begin{tabular}{|c|c|c|c|c|}
\hline No. & Variable & $\mathrm{N}$ & $\begin{array}{c}\text { Mean } \\
\text { score }\end{array}$ & Category \\
\hline 1. & $\begin{array}{c}\text { Memory } \\
\text { strategies }\end{array}$ & 75 & 2.61 & Medium \\
\hline 2. & $\begin{array}{c}\text { Cognitive } \\
\text { strategies }\end{array}$ & 75 & 2.56 & Medium \\
\hline 3. & $\begin{array}{c}\text { Compensation } \\
\text { strategies }\end{array}$ & 75 & 2.66 & Medium \\
\hline 4. & $\begin{array}{c}\text { English } \\
\text { proficiency }\end{array}$ & 75 & 82.07 & Good \\
\hline
\end{tabular}


Based on the data in table 3 above, it could be explained that the mean scores of those three categories of learning strategies were in the medium level of implementation. It can be concluded that the most dominant learning strategy used in learning English was the compensation strategies with the mean score was 2.66, in which this was the highest mean score among other strategies. In comparison, the mean score of English proficiency was 82.07 which was in the good category.

\section{Prerequisite Analysis}

This analysis consisted of two types, those were normality testing and linearity testing. In normality testing, the data were normally distributed if the value of Asymp. Sig. (2tailed) was greater than 0.05 . In testing the normality data, it used a One-Sample Kolmogorov-Smirnov analysis. The result of the analysis was presented below:

Table 4: One-Sample Kolmogorov-Smirnov Test.

\begin{tabular}{|c|c|c|}
\hline & & $\begin{array}{l}\text { Unstandardized } \\
\text { Residual }\end{array}$ \\
\hline \multicolumn{2}{|l|}{$\mathrm{N}$} & 75 \\
\hline \multirow[t]{2}{*}{ Normal Parameters ${ }^{\mathrm{a}, \mathrm{b}}$} & Mean & .0000000 \\
\hline & Std. Deviation & .32930673 \\
\hline \multicolumn{2}{|l|}{ Test Statistic } & .087 \\
\hline \multicolumn{2}{|l|}{ Asymp. Sig. (2-tailed) } & $.200^{\mathrm{c}, \mathrm{d}}$ \\
\hline
\end{tabular}

From the table above, it was known that the value of Asymp. Sig. (2-tailed) was 0.200 , which was higher than 0.05 . Therefore, it could be concluded that the data were normally distributed. The next analysis was linearity testing. To conclude that the data had a linear correlation, the significant value had to be fewer than 0.05 . This analysis was done using Compare Means analysis and the results were as follow:
Table 5: Result of linearity testing.

\begin{tabular}{|c|c|c|c|c|}
\hline No. & Variable & $\mathrm{N}$ & $\begin{array}{c}\text { Sig. } \\
\text { value }\end{array}$ & Result \\
\hline 1. & $\mathrm{X} 1-\mathrm{Y}$ & 75 & 0.00 & Linear \\
\hline 2. & $\mathrm{X} 2-\mathrm{Y}$ & 75 & 0.00 & Linear \\
\hline 3. & $\mathrm{X} 3-\mathrm{Y}$ & 75 & 0.00 & Linear \\
\hline
\end{tabular}

The table above indicated that the significant values of all data were 0.00 , which could be concluded that the data had a linear correlation.

\section{The Relationship between Memory Strategies and English Proficiency}

Since the data were normally distributed and had a linear correlation, then the hypothesis was tested using a parametric statistic, which was a Pearson Correlation Product Moment analysis. The first analysis was to find out whether there were a positive relationship and a significant effect of memory strategies toward English proficiency. The result of the correlation analysis was presented below:

Table 6: Correlations analysis between memory strategies and English proficiency.

\begin{tabular}{|c|c|c|c|}
\hline \multirow{2}{*}{ Strategy } & \multicolumn{3}{|c|}{ English proficiency } \\
\cline { 2 - 4 } & $\begin{array}{c}\text { Pearson } \\
\text { Correlation }\end{array}$ & $\begin{array}{c}\text { Sig. } \\
\text { (2-tailed) }\end{array}$ & $\mathrm{N}$ \\
\hline $\begin{array}{c}\text { Memory } \\
\text { strategies }\end{array}$ & $.756^{* *}$ & .000 & 75 \\
\hline
\end{tabular}

The table above indicated the number of samples was 75 students. The score of Pearson Correlation Product Moment analysis was 0.756 . This meant there was a strong positive relationship between memory strategies and English proficiency. The value of Sig. (2-tailed) was 0.00, which was less than 0.05 . It meant the memory strategies significantly affected English proficiency.

\section{The relationship between cognitive strategies and English proficiency}

The second correlation analysis was to find out whether there were a positive 
relationship and a significant effect of cognitive strategies toward English proficiency. The result of the correlation analysis was presented below:

Table 7: Correlations analysis between cognitive strategies and English proficiency.

\begin{tabular}{|c|c|c|c|}
\hline \multirow{2}{*}{ Strategy } & \multicolumn{3}{|c|}{ English proficiency } \\
\cline { 2 - 4 } & $\begin{array}{c}\text { Pearson } \\
\text { Correlation }\end{array}$ & $\begin{array}{c}\text { Sig. } \\
\text { (2-tailed) }\end{array}$ & $\mathrm{N}$ \\
\hline $\begin{array}{c}\text { Cognitive } \\
\text { strategies }\end{array}$ & $.688^{* *}$ & .000 & 75 \\
\hline
\end{tabular}

The table above indicated the number of samples was 75 students. The score of Pearson Correlation Product Moment analysis was 0.688 . This meant there was a strong positive relationship between cognitive strategies and English proficiency. The value of Sig. (2-tailed) was 0.00 , which was less than 0.05 . It meant the cognitive strategies significantly affected English proficiency.

\section{The relationship between compensation strategies and English proficiency}

The third correlation analysis was to find out whether there were a positive relationship and a significant effect of the compensation strategies toward English proficiency. The result of the correlation analysis was presented below:

Table 8: Correlations analysis between compensation strategies and English proficiency.

\begin{tabular}{|c|c|c|c|}
\hline \multirow{2}{*}{ Strategy } & \multicolumn{3}{|c|}{ English proficiency } \\
\cline { 2 - 4 } & $\begin{array}{c}\text { Pearson } \\
\text { Correlation }\end{array}$ & $\begin{array}{c}\text { Sig. } \\
\text { (2-tailed) }\end{array}$ & $\mathrm{N}$ \\
\hline $\begin{array}{c}\text { Cognitive } \\
\text { strategies }\end{array}$ & $.702^{* *}$ & .000 & 75 \\
\hline
\end{tabular}

The table above indicated the number of samples was 75 students. The score of Pearson Correlation Product Moment analysis was 0.702 . This meant there was a strong positive relationship between compensation strategies and English proficiency. The value of Sig. (2-tailed) was 0.00 , which was less than 0.05 . It meant the compensation strategies significantly affected English proficiency.

This research result is supported by research conducted by Naeimi and Foo (2015) which applying direct and indirect strategies to improve students' vocabulary acquisition. The result indicated that the class that was taught using direct strategies obtain better vocabulary acquisition that the class that was taught using indirect strategies. More specifically, Fourdini et al. (2014) in their research found that cognitive strategies were the most strategies used by the students in learning reading.

\section{CONCLUSION}

In conclusion, it was concluded that there were positive relationships and significant effects of memories strategies, cognitive strategies, and compensation strategies toward English proficiency on the eleventhgrade students. Those three categories of language learning strategies had a strong relationship with the students' English proficiency. Among them, the memory strategies had the highest score of correlation on the students' English proficiency, which was 0.756. Besides, those language learning strategies had the same criteria, which were medium. By looking at the mean score, the compensation strategies got the highest one, which was 2.66. So, it can be concluded that the compensation strategies were the most dominant learning strategy used by the grade eleventh student at SMA Negeri 1 Baubau. 
J-SHMIC : Journal of English for Academic

Vol 7, No 2, August 2020

$E-I S S N=2641-1446, P-I S S N=2356-2404$

\section{ACKNOWLEDGEMENTS}

The researcher would like to highly appreciate the principal of SMA Negeri 1 Baubau for permitting the researcher to take the data in her school, the English teachers, and the students at the eleventh-grade to provide their time so that this research is well conducted.

\section{REFERENCES}

Ang, S., Mohamed Amin Embi, \& Yunus, M. M. (2017). Strategies of successful English language learners among private school students. Jurnal Pendidikan Humaniora, 5(2), 47-57. https://doi.org/10.20961/eed.v5i2.3605 3

Arif, T. Z. Z. Al. (2020). J-SHMIC: Journal of English for Academic. $J$ SHMIC: Journal of English for Academic, 7(1), 66-76. https://journal.uir.ac.id/index.php/jshm ic/article/view/3905

Barruansyah, R. T. (2018). The correlation between learning styles, language learning strategies, and English learning motivation of the sixth semester students of STIBA Persada bunda. Journal of English for Academic, 5(1), 49-62. https://doi.org/https://doi.org/10.25299 /jshmic.2018.vol5(1).1050

Brown, H. D. (2007). Principles of Language Learning and Teaching (5th ed.). Pearson Education. https://doi.org/10.2307/414380

Chamot, A. U. (2005). Language Learning Strategy Instruction: Current Issues and Research. Annual Review of Applied Linguistics, 25(2005), 112130.

https://doi.org/10.1017/S02671905050 00061

Cohen, A. D., \& Macaro, E. (2007). Language learner strategies: Thirty years of research and practice. sidalc.net. http://www.sidalc.net/cgibin/wxis.exe/?IsisScript=SUV.xis\&me thod $=$ post $\&$ formato $=2 \&$ cantidad $=1 \&$ e $\mathrm{xpresion}=\mathrm{mfn}=016587$

Creswell, J. W. (2012). Educational Research (Fourth). Pearson Education.

Darsono, M. (2000). Belajar dan Pembelajaran. IKIP Press.

Djamarah, S. B. (2002). Psikologi Belajar. Rineka Cipta.

Dörnyei, Z., \& Ryan, S. (2015). The Psychology of the Language Learner Revisited. Routledge.

Fourdini, H., Radjab, D., \& Refnaldi. (2014). The Correlation between Students' Language Learning Strategies in Reading \& Their Reading Comprehension at the Second Year of English Department of the State University of Padang. Journal of English Language Teaching, 2(2), 103-110.

http://ejournal.unp.ac.id/index.php/jelt/ article/view/3712

Hornby, A. S. (2010). Oxford Advanced Learner's Dictioanry. Oxford University Press.

Hughes, A. (2003). Testing for Language Teachers (2nd ed.). Cambridge University Press.

Lessard-Clouston, M. (1997). Language learning strategies: an overview for $L 2$ teachers. The Internet TESL Journal.

Mattarima, K., \& Hamdam, A. R. (2011). Understanding students' learning strategies as an input context to design English classroom activities. International Journal of Psychological Studies, 3(2), 238-248. https://doi.org/10.5539/ijps.v3n2p238

Mills, G. E., \& Gay, L. R. (2016). Educational Research: Competencies for Analysis and Applications (Eleventh (ed.)). Pearson Education 
Limited.

Naeimi, M., \& Foo, T. C. V. (2015). Vocabulary Acquisition through Direct and Indirect Learning Strategies. English Language Teaching, 8(10), 142-151. https://doi.org/10.5539/elt.v8n10p142

O'Malley, J. M., \& Chamot, A. U. (1990). Learning Strategies in Second Language Acquisition. Cambridge University Press.

O’Neil, P., Moore, C., \& Huot, B. (2009). A Guide To Collage Writing Assessment. Utah State University Press.

Oflaz, A. (2019). The effects of anxiety, shyness and language learning strategies on speaking skills and academic achievement. European Journal of Educational Research, 8(4), 999-1011.

https://doi.org/10.12973/eu-jer.8.4.999

Oxford, R. L. (1990). Language Learning Strategies. Heinle \& Heinle.

Purpura, J. E. (1997). An analysis of the relationships between test takers' cognitive and metacognitive strategy use and second language test performance. Language Learning, 47(2), 289-325. https://doi.org/10.1111/00238333.91997009

Richards, J. C., \& Schmidt, R. (2010). Longman Dictioary of Language Teaching and Applied Linguistics (4th ed.). Pearson Education Limited.

Saricoban, A., \& Saricaoglu, A. (2008). The effect of the relationship between learning and teaching strategies on academic achievement. NovitasROYAL, 2(2), 162-175.

Schmeck, R. R. (Ed.). (1988). Learning Strategies and Learning Styles. Springer Science+Business Media, LLC.

Shyr, W. J., Feng, H. Y., Zeng, L. W.,
Hsieh, Y. M., \& Shih, C. Y. (2017). The relationship between language learning strategies and achievement goal orientations from Taiwanese engineering students in EFL learning. Eurasia Journal of Mathematics, Science and Technology Education, 13(10), 6431-6443. https://doi.org/10.12973/ejmste/76660

Slameto. (2010). Belajar \& Faktor-Faktor yang Mempengaruhinya. Rineka Cipta.

Susetyo, B. (2015). Prosedur Penyusunan \& Analisis Tes. Refika Aditama.

Suwanarak, K. (2019). Use of learning strategies and their effects on english language learning of thai adult learners. 3L: Language, Linguistics, Literature, 25(4), 99-120. https://doi.org/10.17576/3L-20192504-07

Taheri, H., Sadighi, F., Bagheri, M. S., \& Bavali, M. (2020). Investigating the relationship between Iranian EFL learners' use of language learning strategies and foreign language skills achievement. Cogent Arts and Humanities, 7(1), 1-38. https://doi.org/10.1080/23311983.2019 .1710944

Tavakoli, H. (2012). A Dictionary of Research Methodology and Statistics in Applied Linguistics. Rahnama Press.

Wong, L. L. C., \& Nunan, D. (2011). The learning styles and strategies of effective language learners. System, $39(2)$, 144-163. https://doi.org/10.1016/j.system.2011. 05.004

Yustitiasari, H. (2020). The relationship between language learning strategies used by vocational students and level of proficiency. E-Journal of Linguistics, 14(1), 128-136. 


\section{APPENDIX}

Direct Learning Strategies Inventory (Adapted from SILL by Oxford, 1990)

1. I think of relationship between what I already know and new things I learn in English.

2. I use new English words in a sentence so I can remember them.

3. I connect the sound of a new English word and an image or picture of the word to help me remember the word.

4. I remember a new English word by making a mental picture of a situation in which the word might be used.

5. I use rhymes to remember new English words.

6. I use flashcards to remember new English words.

7. I physically act out new English words.

8. I review English lesson often.

9. I remember new English words or phrases by remembering their location on the page, on the board, or on a street sign.

10. I say or write new English words several times.

11. I try to talk like native English speakers.

12. I practice the sounds of English.

13. I use the English words I know in different ways.

14. I start conversation in English.

15. I watch English language TV shows spoken in English or go to movies spoken on English.

16. I read for pleasure in English.

17. I write notes, messages, letters, or reports in English.

18. I first skim an English passage (read over the passage quickly) then go back and read carefully.

19. I look for words in my own language that are similar to new words in English.
20. I try to find patterns in English.

21. I find the meaning of an English word by dividing it into parts that I understand.

22. I try not to translate word-for-word.

23. I make summaries of information that I hear or read in English.

24. To understand unfamiliar English words, I make guesses.

25. When I can't think of a word during a conversation in English, I use gestures.

26. I make up new words if I do not know the right ones in English.

27. I read English without looking up every new word.

28. I try to guess what the other person will say next in English.

29. If I can't think of an English word, I use a word or phrase that means the same thing. 